STATE OF ILLINOIS

DEPARTMENT OF REGISTRATION AND EDUCATION

DIVISION OF THE

NATURAL HISTORY SURVEY

STEPHEN A. FORBES. Chief

Vol. XVII. BULLETIN Article VI.

\title{
Some Causes of Cat-facing in Peaches
}

BY

B. A. PORTER,

U. S. Bureau of Entomology. Vincennes. Indiana

S. C. CHANDLER.

Illinois Natural History Survey. Carbondale. Illinois

R. F. SAZAMA,

U.S. Bureau of Entomology, Vincennes, Indiana

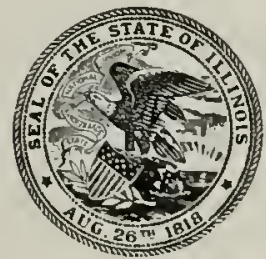

PRINTED BY AUTHORITY OF THE STATE OF ILLIINOIS

URBANA, ILLINOIS

March, 1928 
STATE OF ILLINOIS

DEPARTMENT OF REGISTRATION AND EDUCATION

A. M. Sfrelton, Director

BOARD OF

NATURAL RESOURCES AND CONSERVATION

A. M. ShelToN, Chairman

William Trelease, Biology

HeNry C. Cowles, f'orestry

Eoson S. Bastin, Geology

William A. Noyes, Chemistry
JoHx W. Alvond, Engineering

Charles M. Thompsox, Represcnting the President of the University of Illinois

THE NATURAL HISTORY SURVEY DIVISION

Stephen A. Forbes, Chief

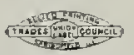

Schnepp \& Barnes, Printers

SFri NGField, Ill.

1928

$82971-3 \mathrm{II}$ 


\title{
SOME CALSES OF GAT-HACING IN PLACHIS*
}

\author{
B. A. Porter, S. C. Chandler, and R. F. Sazama
}

\section{INTRODUCTION}

For a number of years the peach growers of sonthern Illinois and southern Indiana, as well as those of some other sections of the Middle West, have been suffering losses from a peculiar deformation of the peaches that generally has been supposed to be causerl by the feeding of thrips. The injury has been named "cat-facing" by growers in several localities, and this term is now in common use in the Middle Mest. Similar injuries occur in peach orchards in the Northwest. in Georgia and the Carolinas, and probably in other localities, but the present paper reports investigations restricted to southern Illinois, southern Indiana, and western Kentucliy.

\section{NATURE OF THE INJUKK}

The injury known as cat-facing usually consists of scarred sunken areas around which the tissues are more or less distorted, but it sometimes takes the form of closed lesions, which vary from slight dimples or depressions to extensive puckered areas. No pubescence develops on an injured area, and in most cases the area is brown, corky, and harder than the normal flesh of the fruit. Such injury is obviously: the result of the feeding of insects when the peaches are small. The more open scars suggest surtace feeding by some kind of chewing insect. but the other scars lonk more like the work of sucking insects.

On a given tree, the injury sometimes tends to be localized: white some parts may be free of injury, almost all of the peaches on other parts may be disfigured. Apparently. the insects causing the injury often move from peach to peach, injuring almost every one they encounter.

Different varieties of peaches appear to be injured in varying degrees. The J. H. Hale often shows more cat-facing than the Elberta grown nearby. One instance has been observed in which at least?? per cent of

* The investigations on which this paper is based were conducted simultaneously at two places at the entomological field labriatory maintained by the Illinois state Natural History Survey at Carbondale, Illinois, under the direction of Mr. IV. F. Flint, and at the field laboratory maintained at Vimcennes. Indiana, by the U. S. Burean of Entomology, under the general supervision of IT. A. L. Quantance, and in cooperation with the Furdue Cniversity Agricultural Experiiment sitation.

Acknowledgment is made to Mr. W. L. McAtee, of the Fureau of Eiological Sulvey, for the determination of the species of Lygus and Euschistus referred to in this paper. 
the peaches on Redbird trees were injured, while only 11 per cent of those on the J. H. Hale nearby were injured, and only 5 per cent of those on the Elberta next to them.

\section{Losses}

The commercial losses resulting from cat-facing are hard to estinate. The percentage of peaches damaged is very variable. Althongh in individual orchards the injury has run as high as 50 per cent or even 66 per cent, the general average in this region is less than 15 per cent.

\section{TABIE I}

\begin{tabular}{|c|c|c|c|c|}
\hline \multirow{2}{*}{ Year } & \multirow{2}{*}{ Orchards examined } & \multicolumn{3}{|c|}{ Per cent of peaches cat-faced } \\
\hline & & Maximum & Minimum & Average \\
\hline 1925 & 25 & 45 & 2 & 14.0 \\
\hline 1926 & 41 & 17 & 0 & 2.6 \\
\hline 1927 & 19 & 24 & 6 & 12.4 \\
\hline
\end{tabular}

Cat-faced peaches usually are graded as No. 2 fruit, and those most severely injured are classed as culls. The actual money loss, of course, varies with market conditions. In years of large crops, the injured peaches are hard to sell, although the loss per bushel is not so great. In years of light crops, the loss per bushel is greater, but most of the lowergrade peaches find a ready market at fair prices.

When the insects causing cat-facing are very abundant, they often cause many of the small peaches to shrivel and drop, so that the crop loss is much greater than the percentage of disfigured fruit at harvest time would indicate. This loss is often very serious, although it may be mnoticed by the grower, or at least not attributed to its real cause. The actual commercial loss that results from the dropping of the fruit varies with the size of the crop and is very hard to measure. In years of heavy bloom, when many surplus peaches set, this loss may be comparatively slight, but in years when there is a light set of fruit. it may be more serious because of the greater proportion of peaches injured.

\section{Procedure}

In order to determine which insects cause cat-facing, different suspects were caged with peaches on the tree. Various cages were used, but the one that proved the most satisfactory was a cylinder of 16 -mesh wire screening, four inches in diameter by six to nine inches in length. fitted 
at one enrl with a cloth sleeve. (See Figure 1.) Such cages may be made readily to enclose a twig bearing two to four small peaches. In most cases the cages were put into place immerliately following petal fall. Wherever it was necessary to cage larger peaches, they were carefully examined, and all those showing any sign of injury were rennoved. In no case dicl injury apjear in check cages.

Several seasons of experience were required to enable the writers to manipulate the cages so as to produce the maximum number of typical injuries. Complete proof of the "guilt" of insects suspected as agents is not obtained as easily as may be supposed. The mere fact that an insect injures a peach when caged with it and cleprived of other food, is not in itself complete proof that the insect is cansing cat-facing in the orchart.

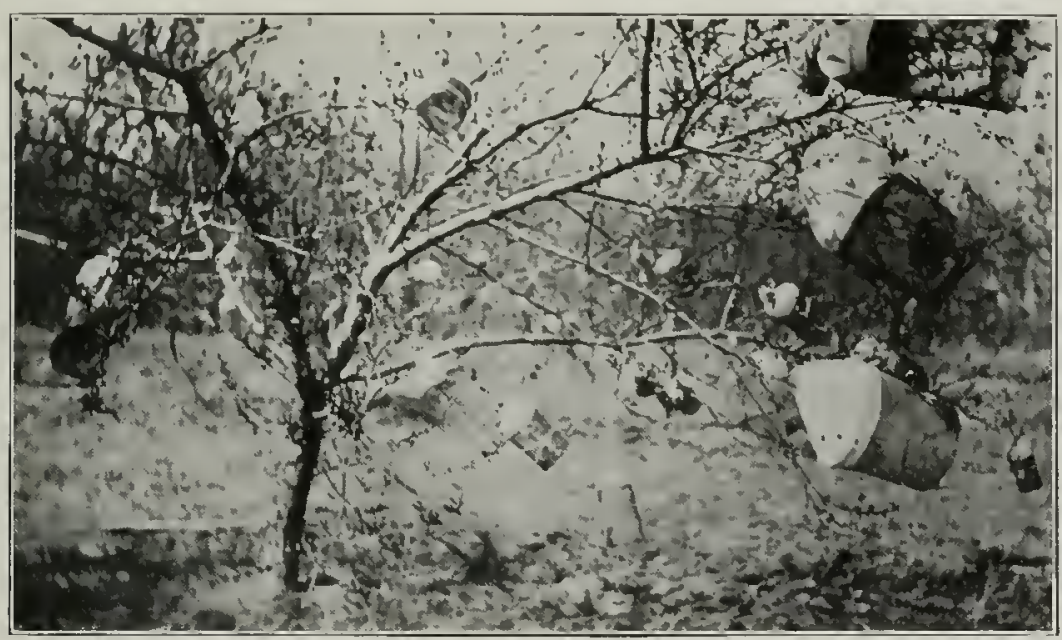

Fig. 1. Tree showing cages used in determining what insects cause catfacing in peaches. Carbondale, Illinois. 1926.

Field obscrvations are necessary in order to detemine whether or not it normally feeds on peaches in the open. On newly formed peaches it is difficult to adjust the period of insect feeding so that the injury will not be overdone and catse the peaches to drop. When the peaches are further developed before being injured, they are less likely to drop: but the normal feeding period of certain of the insects, at least, is then nearly over, and the resulting lesions are not so closcly similar to typical catfacing. All of the insects that we consiler responsible for cat-facing have been observed repeatedly in the orcharil in the act of feeding on peaches. with their mouth parts actually inserted into the peach tissue. This is the final step in retermining the causal agents. 


\section{SOME INSECTS THAT CAUSE CAT-FACING \\ The Tarnisiled Plant Bug}

The Tarnished Plant Bug (Lygus pratensis L.) has been recorded a number of times as feeding on peaches, particularly by Lowe ${ }^{1}$ and Taylor. $^{2}$ This small, inconspictuous bug (see Figure 2) came under suspicion several years ago as a possible cause of cat-facing, and the type of injury done by it was described in a previous paper by Porter. ${ }^{3}$ The fresh injuries consist of rather extensive irregular areas of broken-down tissue." In some cases the skin is left intact except for a central puncture, but in

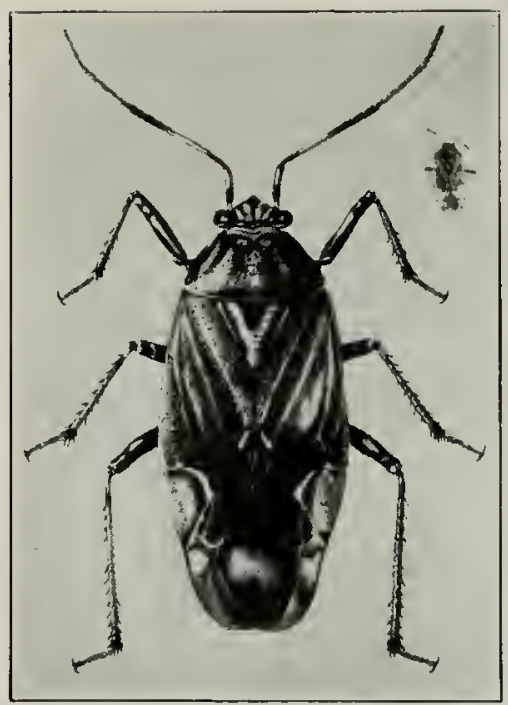

FIG. 2. Tarnished Plant Bug, Lygus pratensis L. (Insert is approximately natural size.)

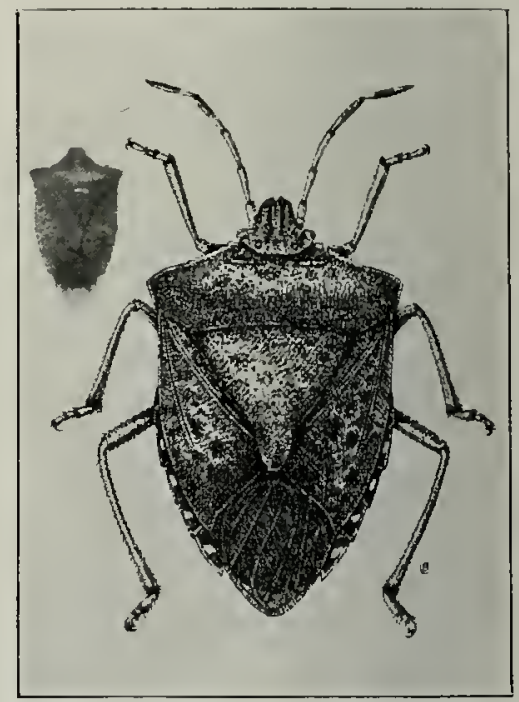

Fig. 3. Stink bug, Euschistus servus (Say). (Insert is approximately natural size.)

others the skin as well as the underlying tissue is broken down. The fuzz over the lesion is usually undisturbed, although the point where the beak of the bug was inserted may be marked at first by a yellowish or brownish stain, which later turns black. If the skin has not already broken down, it dries and sloughs off, and the inner surface of the cavity becomes corky and rough as it heals over. The surrounding tissues usually grow more rapidly than the injured spot, producing more or less distortion. The bugs in feeding apparently inject some poisonous material that canses

${ }^{3}$ Lowe, V. H., 1900. Miscellaneous Notes on Injurious Insects. New York Agr, Exp. Sta. (Geneva) Bull. 180, p. 135.

2 Taylor, E. P. 1908. Dimples in Apples from Oviposition of Lygus matensis L. J. Ec. Ent. 1, p. 370 .

Porter, B. A., 1926. The Tarnished Plant Bug as a Peach Fruit Pest. J. Ec. Ent. 19 , pp. $43-48$. 
the tissues to disintegrate. Hypodermic injections of the juices of crushed bodies of the bugs produced lesions somewhat similar to catfacing, but injections of distilled water. as well as injuries produced by probing with a sterile needle. tailed to result in such lesions.

Peaches injured in cages by the Tarnished Plant Bug were carried through to the mature cat-face stage in 1929 and 19:2. thus completing the proof that this insect plays a part in the production of cat-facing. Two of these peaches are show'n in Figure 4.

The bugs that feed on peaches in spring are those that have becone full-grown in the previons antumn and have passed the winter in the adult stage in or near the orcharc. The Tarnished Plant Bug normally: passes its life on varions weeds and other succulent plants. It seems to be especially fond of the plants in the daisy fanily, stch as wild asters and

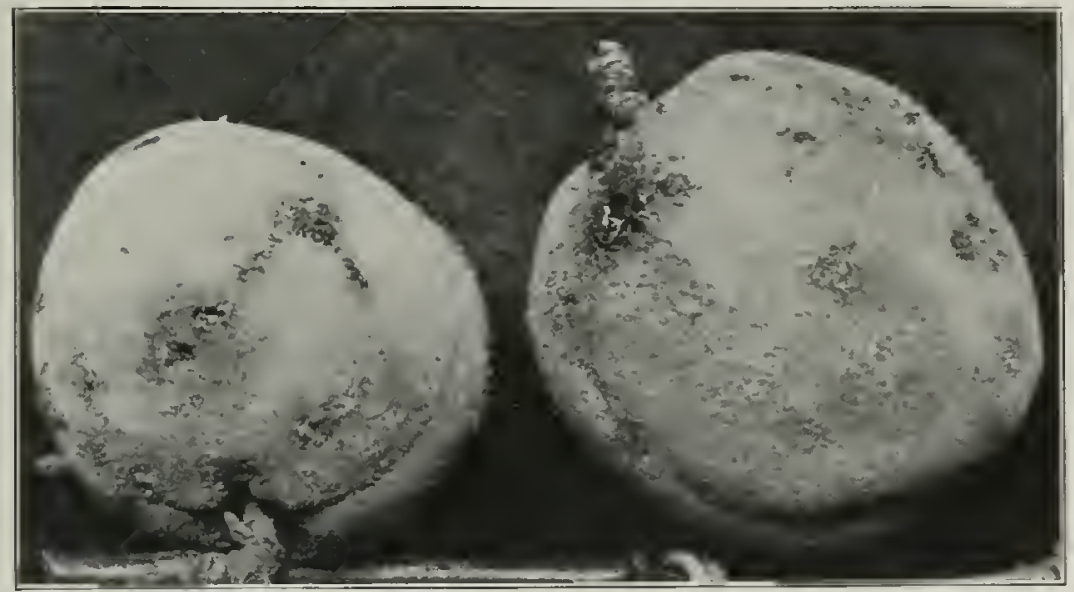

Fig. 4. Peaches injured in cages by Tarnished Plant Bug. Carbondale. Ittinois. 1926.

fleabanes, an well as the leguminous plants. such as red clover. altalia, and sweet clover. These last two also provide the bugs with rery acceptable hilsernating quarters, since. in addition to winter protection. they furnish satisfactory food very late in fall and very early in spring.

Many of the hibernating bugs are attracted to the peach blostons. and for a period of two or three weeks they do the feeding that results in the injuries just described. The approximate period during which the bugs are present on the trees, as indicated by the number of bugs caught on the sheets when jarring for curculio, is shown in Figure i. Very few eggs are laid on the peach trees, and atter a short time most of the bugs desert the trees and return to various weeds or cultivated crops to lay their eggs. The Tarnished Flant Bug is said to pass throngh several generations during a season, and to hibernate almost entirely in the adult stage. 


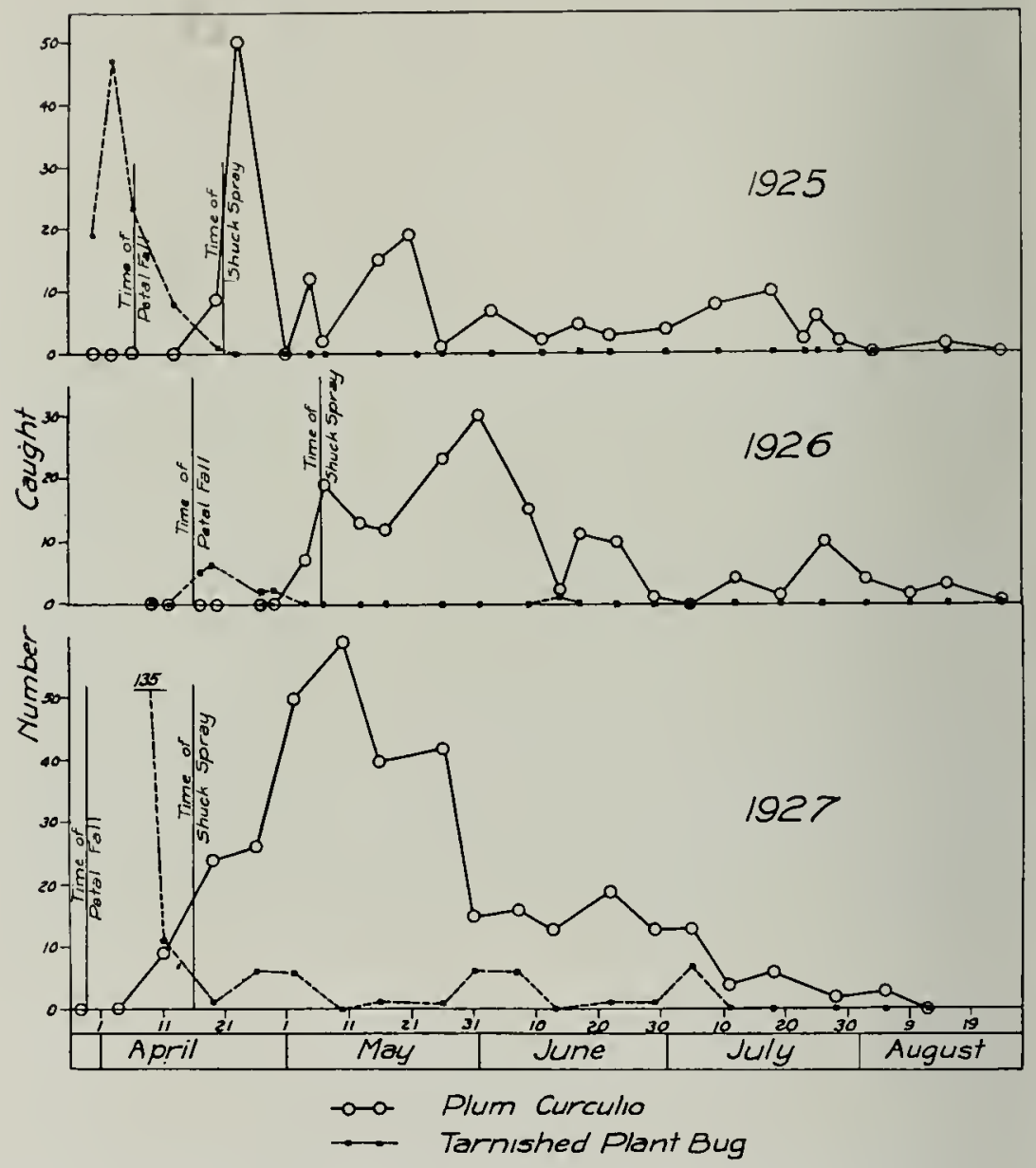

Fig. 5. Graphs showing numbers of Tarnished Plant Bug and Plum Curculio caught on sheets by early-morning jarring of 10 unsprayed peach trees, Carbondale, lllinois. The jarring was done between 6:00 and $7: 00 \mathrm{a} . \mathrm{n}$. The insects were turned loose after counting. in order to keep conditions as near natural as possible. 


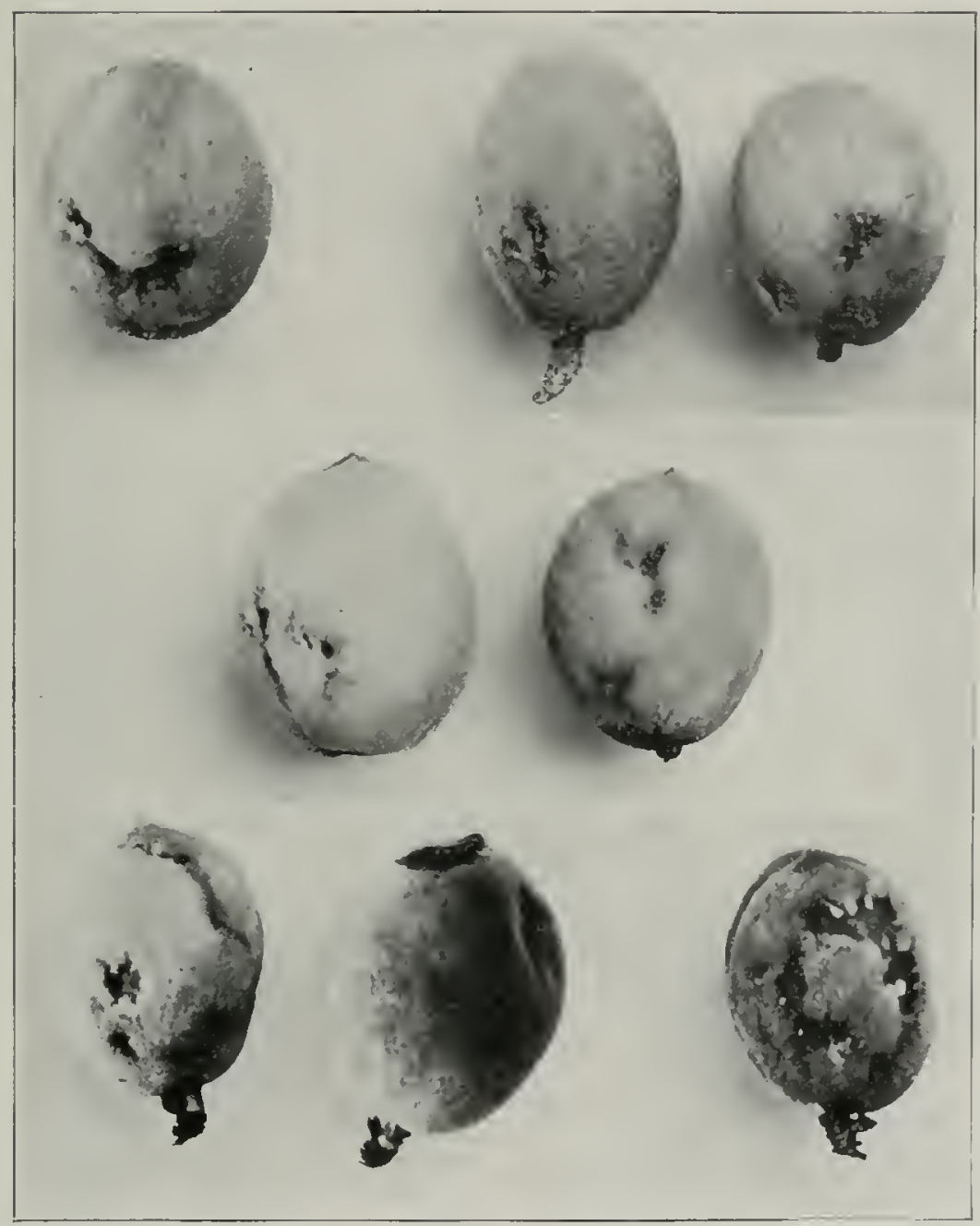

Fig. 6. Peaches injured in cages by three kinds of stink bugs: top row. Euschistus variolarius: middle row, $E$. tristigmus: bottom row. $E$. servus. V'incennes, Indiana. 1927. Photos by R. L. Coffin. of Japanese Bectle Laboratory. 


\section{STINK Bugs}

Four species of st:nk bugs* produce cat-facing. (See Figures :3 and 6.) These large, angular bugs, gray to brown in color, a re often very abundant in peach orchards in spring, and we have observed them repeatedly in the act of feeding on small peaches. When the peaches are very small, most of the injured ones shrivel and drop, but when the peaches are larger, most of those that have been fed upon remain on the tree and become distorted or cat-faced. The stink bugs continue to produce cat-facing for five or six weeks after petal fall, or until the peaches become an inch or more in diameter. Feeding continues after this stage of development, in diminishing amounts, and the lesions produced later are less extensive. Two of the species involved, E. variolarius and $E$. tristigmus, were very abundant during $192 \%$ in southern Indiana, and the

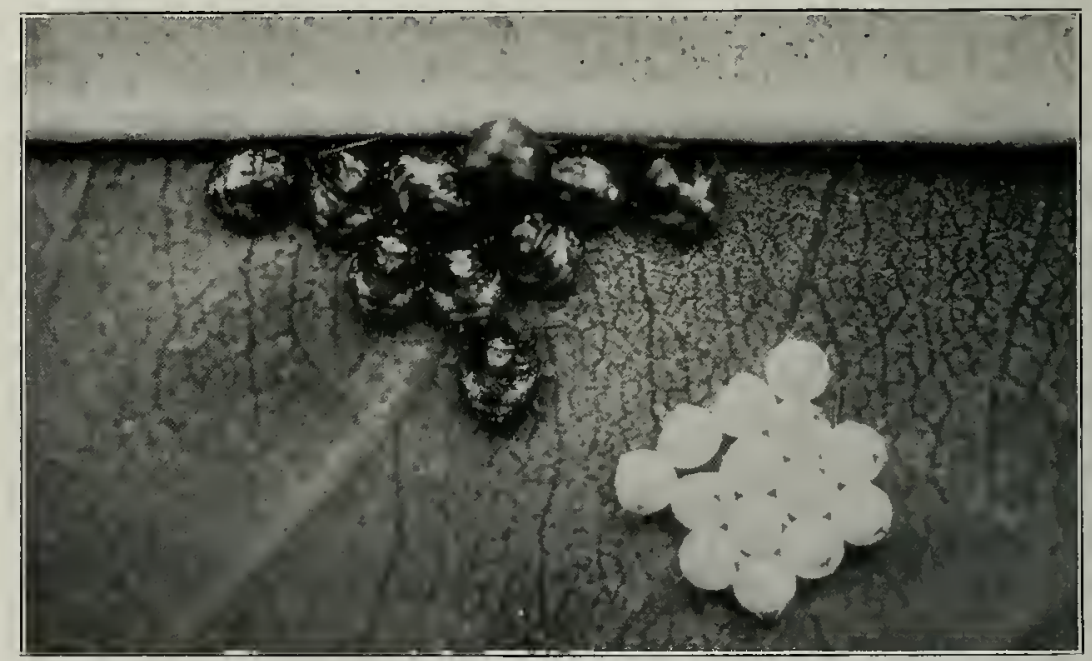

F1G. 7. Colony of small stink bugs, clustered on leaf near egg mass from which they hatched. Vincennes, Indiana. 1927. (About six times natural size.)

other two species mentioned were probably responsible for very little of the cat-facing there in that season.

A few of the stink bugs lay eggs in small groups on the leaves of the peach trees. The egg masses observed have usually been in 1nultiples of seven, fourteen being the most common number. On hatching, the young bugs remain clustered around the egg mass for a few days until they undergo the first molt (see Figure $\hat{\imath}$ ) : they then disperse and feed for a short time on the leaves and on the young peaches, if they find any nearby.

* Euschistus variolarius (Palisot de Beauvois); E. euschistoides (Vollenhoven) ; $E$. sfrvus (Say); and E. (ristigmus (Say). These are the nore common menbers of this genus in southern lllimois and southern Indiana. 
Their feeding may cause slight dimples on the fruit, out of which ooze small quantities of gum; this kind of injury, however, is not very common, since the small bugs disappear from the peach trees soon after the first molt. They are found in abundance on weeds in the orchard in early summer, particularly on the young plants of one of the fleabanes. Erigcron canadensis L. I Later on, bugs of all ages nay le found in large numbers in fields of soy beans and cow peas. In $192 \%$, one of the stink bugs (E. z'ariolarius) was found in large numbers in red clover fields. They nlay be found, however, to a greater or lesser extent on almost any growing plant. Stink bugs are said to pass usually through two generations cluring a season, and they hibernate in the aldult stage.

\section{Curculan}

The Plum Curculio, Conotrachchs nemuphar Herbst, so well known to all peach growers, produced cat-facing on peaches in our cages. The

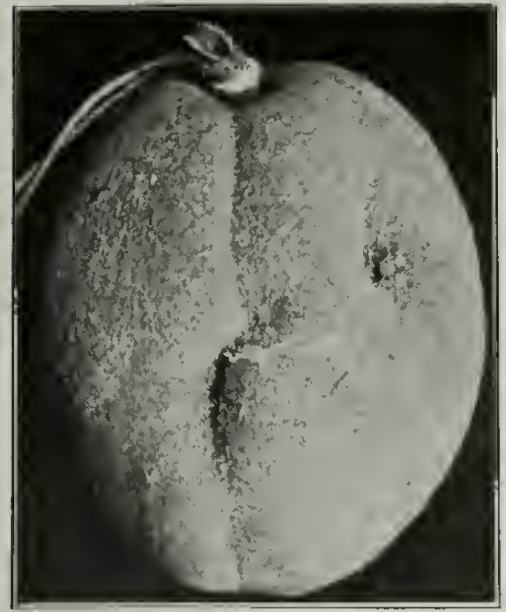

F1r. S. Peach injured in cage by curculio. Carbondale, Illinois. 1926 .

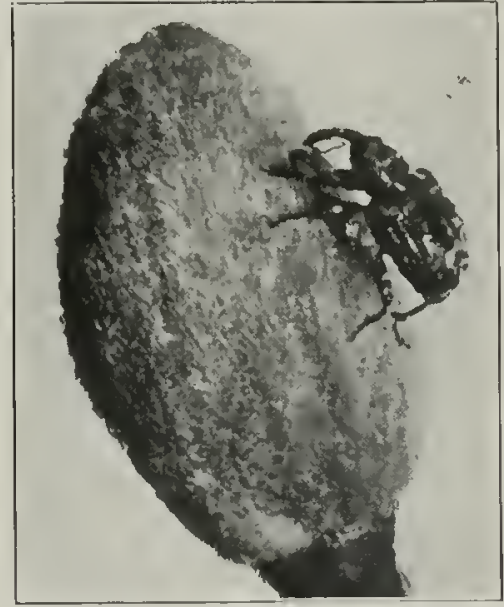

Fic. 9. Curculio ovipositing on a peach. (About four times natural size.)

work of this insect is best known to the growers ly the dropling of peaches early in the season and the occurrence of womy fruit at harvest. When the injured fruit remains on the tree, it is more or less distorted. (See Figures 8 and 9.)

\section{Other Pussible cineses}

While we are confident that the list of insects already named includes the important causes of cat-facing in sonthern lllinois and southern Indiana, it is probable that further investigations will show that other insects are also capable of producing cat-facing. 
The Green Soldier Bug, Acrostcrnum hilare (Say), one of the largest of the stink bugs, is occasionally seen in peach orchards, and its young stages sometimes cause considerable injury to the fruit ${ }^{t}$ in the form of numerous small dimples (see Figure 10). None of the mature bugs have been available for caging tests in spring. A few peaches may be catfaced by this species. Jut it is so scarce in the peach orchards of this section that it cannot be an important factor.

A species of thrips, Frankliniclla tritici (Fitch), which is often present in large numbers in the peach blossons and around the small fruit, was at first suspected as the canse of cat-facing, but we have been tunable to connect this insect with the trouble. In one season in particular (1925) thrips were very abundant in our cages (they are so very small that they can pass through the ordinary screen cage), but no sign of injury appeared until other insects were introduced. Even when the normal population was angmented by the addition of fifteen to twenty thrips to each

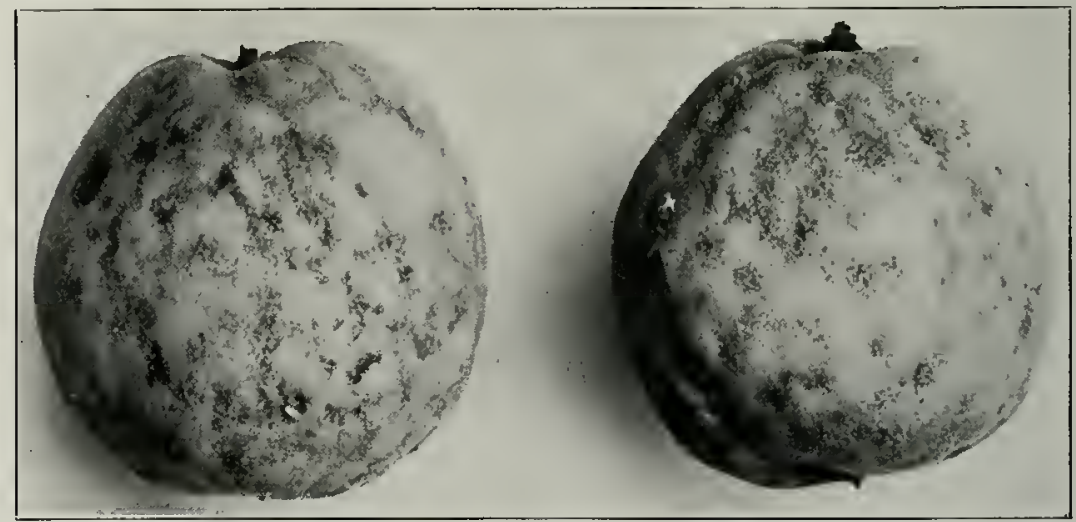

FIg. 10. Peaches injured by young of Green Soldier Bug, Acrosternum hilare (Say). Vincennes, Indiana, 1927. Photo by R. L. Coffin, of Japanese Beetle Laboratory.

peach, no injury appeared. Field observations and counts have failed to show any relation between thrips abundance and amount of cat-facing. The fruit in some orchards in which thrips have been almost entirely absent has suffered severe cat-facing. As a result of these studies, we believe that the work of thrips is a negligible factor.

\section{Relative Importance of the Different Insects}

We can make no definite statement at present that will hold true for every year, or in every peach section, or even in all parts of the same section, as to the relative importance of the different species implicated in

\footnotetext{
310.

tWhitmarsh, R. D., 1917. The Green Soldier Bug. Ohio Agr. Exp. Sta. Bull.
} 
prodincing cat-facing. The curculio is probal)ly of less importance in this respect than the sucking bngs-a belief which is supported by the fact that serious cat-facing injury occurs in some peach orchards in the Iacific Northwest where the curculio does not occur.

If it were possible to distinguish the injury caused by each of the different insects, it conld be retermined which insect is of the greatest importance in inclividual orchards. Although the different injuries when fresh may be identified with some degree of certainty, they cannot be distinguished che from another after they have healed over.

\section{HOST l'LANT RELATIONS}

With the exception of the Plum Curculio, which is probalyly a lesser factor, the insects involved in this problem do not breed to any extent on peach. They are very general feeders, and may be found on any one of a long list of food plants. The Tamished Plant Bug seems to favor plants in the family Compositae, especially the daisies, the fleabanes, and the wild asters. It also breeds freely on the legunes, but may be found on almost any other plant. ${ }^{3}$

The stink bugs are, likewise, very general feeders and may be found on a great nuany different kinds of plants. Inong their preferred host plants may be mentioned red clover, cow peas, and soy beans. The presence of these bugs on peach fruit in the spring is merely incidental and in no way essential to their life eycle.

The plant relationships of the Plum Curculio are not as extensive as those of the other insects involved. Of the cultivated plants aside from peach, the curculio feeds regularly on apple. plunt, cherry and other fruits, which are often planted close to peach orchards. Of the wild host plants, wild haw and wild plum are probably the most important.

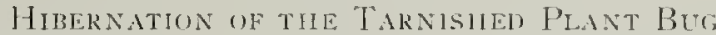

Studies were made of the hibernating habits of the Tarnished Plant Bug in an effort to discover sone means of controlling this canse of catfacing. The bugs were found in a variety of winter habitats; some in clumps of clover and alfalfa in fields where numbers of them had been observed to be feeding in late smmmer and antumn: some under fallen leaves of trees at the elges of these fields; a tew in apjle orchards under various kinds of cover, such as grass, leaves, and bits of bark: and a few in other places wherever there was sufficient cover. The wolly leaves of mullein seem to be the most favored winter quarters in this section of the comntry, for the lungs are usually to be found in mullein even when difficult to find elsewhere. Is many as fifty of them have been found at one time in a single plant. The highest average found in any one peach district was eighteen bugs per plant.

Nany 'lamished Plant Bugs do not go into true hibernation, but leave their winter quarters on warm days. Counts made on November

${ }^{5} \mathrm{Fu}^{\circ}$ a detailed discussion of host plants of the Tarnished I'lant Fug. see Comell Bulletin No. 346 , "The Tarnished Plant Lug", piges $467-472$, by $\mathrm{C}$. R. Crosby and $M$. I). Leunat. 1914. 
2\%. 1996, near Carbondale. Illinois, showed an average of five bugs per square foot under hickory leaves at the edge of a sweet clover field. Counts made nine days later, in exactly the same places, after several mild* days had intervened, showed an arerage of only one bug in five square feet. On three occasions all the hibernating bugs were removed fron certain mullein plants in an alfalfa field near Anna, Illinois; two or three days later, when these plants were examined, they were found to harbor as many bugs as had been present originally.

\section{Control of tue Tarnished Plant Bug And the Stink Bugs}

Insecticidal Control. It is very difficult, if not impossible, to control the Tarnished Plant Bug and the stink bugs by sprays or dusts. Arsenate of lead, and other stomach poisons, have no effect on this group of insects, since their food is obtained by sucking the plant juices. They may be killed only by direct contact with the spray or dust. At the time when the fruit needs protection, the bugs are in the adult stage, very active and difficult to hit with a spray, and very resistant to ordinary contact materials. Even if it were possible to kill all the bugs on the trees at a given time, reinfestation would be likely to occur from weeds in the orchard or from nearby sources, if such sources of infestation exist. After their period of attack on the small peaches, the bugs return to their normal breeding plants in the orchard or in its vicinity. There is, therefore, no opportunity to attack the young stages of the bugs on the trees in the orchard. The treatment of the immature bugs on the weeds would be impracticable because of the extensive area that would ordinarily have to be covered both in and around the orchard. Another disadvantage of a general insecticide treatment of this nature lies in the fact that it would have to be applied during the summer or antumn in order to protect the following season's crop, and such efforts would be wasted in the event of subsequent loss of the peach crop by winter-killing or spring frosts.

Cagc Tests. Because the Tarnished Plant Bugs are so active, our experimental work with contact insecticides has been largely with dusts, which we hoped might envelop them before they had time to escape. Before any orchard tests were made it seemed advisable to make tests to ascertain whether the bugs could be killed at all. Accordingly, numbers of Tarnished Plant Bugs and stink bugs were placed in screen wire cages ( 5 by 5 by $2 \pm$ inches) and subjected to excessively heavy spraying and dusting, with results as shown in Table II.

In interpreting the results of these preliminary tests, it should be borne in mind that the materials were used in excessive amounts and at high strengths, and that the insects were closely confined and had no opportunity to escape.

* Maximum temperatures ranged from $3 S^{\circ} \mathrm{F}$. to $66^{\circ} \mathrm{F}$. during this period, reaching $61^{\circ}, 62^{\circ}$, and $66^{\circ}$ on three of the nine days. 
Control in the Orchard. In using these materials in the orchard. growers are certain to encounter serious difficulties. Contact dusts are essentially open-air fumigants, and their successful use requires a very still atmosphere. In addition, the nicotine dusts recpuire temperatures of at least $70^{\circ} \mathrm{F}$. for effectiveness. Weather conditions that permit effective use of contact dusts seldom occur during the brief period when these bugs are present in the peach orchards. In fact, low temperatures, high winds, and frequent rains made it impossible to do effective dusting during the critical period in the spring of 192. All of these materials are very expensive, and even if control conld be obtained with them. the cost wotld be high, if not prohibitive.

The time during which dusting can be done effectively is short, as will be seen by the graphs in Figure is. Very little control of the Tamished [lant Bug would be possible if the operation were delaved for a week.

Repellents. Since feerling by the bugs on peaches in spring is not at all necessary to then in their life economy, we have considered the possibility of applying some kind of material that would repel them from the

Restits of Phelimiary Experinexts ix the Coxtrol of Tarxisifin Plaxt Beg axd Stixis Bigs. (1xsects Coxfixed ix Cages -ixi) SUbJectiol to Healy Doses.)

\begin{tabular}{|c|c|c|}
\hline Materials and dosages & $\begin{array}{l}\text { Tarnished } \\
\text { Plant Bug } \\
\text { Per cent killed }\end{array}$ & $\begin{array}{l}\text { Stink Bugs } \\
\text { Per cent killed }\end{array}$ \\
\hline DISTS & & \\
\hline Calcium cyanide $17-25 \% \ldots \ldots \ldots \ldots$ & 24 & 60 \\
\hline Calcium cyanide $40-50 \% \ldots \ldots \ldots \ldots \ldots$ & 90 & 40 \\
\hline Sulfur-cyanide ${ }^{2} \ldots \ldots \ldots \ldots \ldots \ldots \ldots \ldots$ & 100 & . \\
\hline Sulfur-naphthalene $50-50 \ldots \ldots \ldots$ & 25 & . \\
\hline Nicotine $2.5 \% \quad \ldots \ldots \ldots \ldots \ldots \ldots \ldots \ldots$ & 0 & . \\
\hline 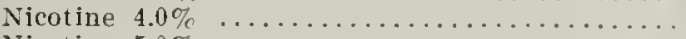 & $\$ 5$ & 90 \\
\hline $\begin{aligned} \text { Nicotine } 5.0 \% & \ldots \ldots \ldots \ldots \ldots \ldots \ldots \\
& \text { SPRAYS }\end{aligned}$ & 100 & . \\
\hline Nicotine sulfate $1-1000 \ldots \ldots \ldots \ldots \ldots \ldots \ldots$ & 12 & . \\
\hline 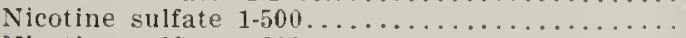 & $\$ 4$ & $\cdots$ \\
\hline Nicotine sulfate $1-200 \ldots \ldots \ldots \ldots \ldots \ldots \ldots \ldots$ & 92 & 0 \\
\hline Sodium oleate-oleo-resin of pyrethrumis $1-15 \ldots$. & 28 & 0 \\
\hline
\end{tabular}

Commercial calcium cranide mixtures containing the indicated amounts of calcium evanide.

2 Commercial dusting mixture, containing 50 per cent sulfur and 20 pe ("ent calcium cyanide.

${ }^{3}$ Home-mixed dusts of hydrated lime and nicotine sulfate, giving the indicated amounts of actual nicotine.

4 Used with fish-oil soap, 2 lbs, in 50 gallons.

5 A commercial stock material. made after the formula cletoped by the Japanese Beetle Laboratory. 
peach trees during the period when cat-facing is being caused. This should be easier than it would be to repel insects that must also use the peach trees or fruit for egg-laying and the nourishment of their young. In order to test possible repellents, a screen wire cage $\left(5^{\prime \prime} \times .^{\prime \prime} \times 2 \cdot t^{\prime \prime}\right)$ was constructed into which Tarnished Plant Bugs were introduced at different times. The following materials were placed at different points in the cage: nicotine sulfate, creosote, naphthalene flakes, carbolic acid, wormseed oil, cresylic acid, lemon oil, oil of citronella, oil of pennyroyal, hydrated lime. No evidence was obtained that any of these materials were in the least degree repellent to the Tarnished Plant Bug. Stink bugs probably would be even more difficult to repel.

Cultural Control. Since the bugs that cause cat-facing breed almost entirely on plants other than peach, a certain degree of control probably may be accomplished by the right sort of cultural practices. The host plant relations and hibernating habits of these insects have already been discussed. Observations have been made as to the influence of different cover crops in the orchard, of farm crops or weedy or wooded areas nearby, and of the presence or absence of favorable hibernating quarters near the orchard. A greater accumulation of data is needed, however. before recommenclations can be made.

\section{Control of the Curculio}

The amount of cat-facing caused by the Plum Curculio can be reduced by means of a more thorough and timely use of sprays. As most of the injury is caused while the peach is still small, and the curculios first begin to appear in large numbers in the orchard about two weeks after petal fall (see Figure 5), the "shuck spray" is the most important application for this purpose. The full schedule is important, however, since the number of curculios which are allowed to breed will have a bearing on the early infestation the following spring. Additional control measures include cultivation in early summer to destroy the delicate pupae in the ground, and the elimination of hibernating cuarters, stich as weed and brush growth in, and close to, the orchard.

\section{TIIINNING}

While thinning camnot be classed properly as a control measure, it does provide a means, especially during seasons of large crops, of reducing the losses caused by cat-facing. Since the usual thinning process on heavily loaded trees often involves the removal of nearly half of the total set of fruit, the removal of all the peaches that show cat-facing would not reduce the total number of bushels harvested, unless the trees were carrying a light crop.

Cat-face injury may be detected much more readily as the peaches become larger, as shown by recent experiments in Illinois. ${ }^{6}$ Fortunately,

\footnotetext{
- Unpublished data by M. J. Dorsey and R. L. McAlunn, University of Illinois.
} 
other experinents by Dorsey and Mc.Mlmun' have indicated that effective thimning may he done as late as four weels before harvest. Which is later than has heretofore been the practice. If extensive cat-face injury is apparent, the grower will therefore find it advantageous to defer thinning as late as possible, in order that a higher percentage of the injurcd peaches may be found and removed.

\section{SUMMARI}

l'each cat-facing is a scarred and distorted condition of the fruit. which causes serions losses in some seasons in the peach-growing sections: of the Midlle West and elsewhere.

The investigations reported in this paper have proved that at least six species of insects have a part in the production of cat-tacing. These insects are the Tarnished Flant Bug, the Flum Cureulio, and four species of stink bugs.

The curculio goes through its life cycle on peach and other fruits. The other insects, all of which are sucking hugs. breed on a wide variety of plants. They do not breed to any extent on peach, and they feed on the peach fruit for only a short time in spring.

No methorl of complete control of the Tarnished Plant Bug and the stink bugs is at present available. Insecticicle treatments are unsatisfactory because these bugs are very active, and because they are very resistant to the most powerful contact nuterials known. Proper adjustnient of cultural practices, to avoid the growth of weeds and certain crops in the orchard or in nearly fields, seens to offer pronise of partial control.

Rerluction in cat-facing cansed by the Flunn Curculio may be accomplished by following recommenrled control measures. mainly by spraying or clusting and cultivation.

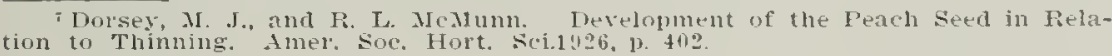

